\title{
INTERACTION OF PARLIAMENTS WITH EXECUTIVE BRANCHES IN POST- SOCIALIST ROMANIA AND KAZAKHSTAN: COMPARATIVE ANALYSIS
}

\author{
Timur Kanapyanov $^{1}$, Naubat Kaliyev ${ }^{2}$
}

\begin{abstract}
Studies on legislature-executive relations have gained a crucial place in the field of comparative politics. However, the most intriguing challenge for comparative political studies has been investigating the collapse of socialist regimes and development of new institutions in post-communist and post-Soviet countries. Accordingly, this article compares legislative-executive relations in Kazakhstan and Romania, in a longitudinal perspective, from the time of communism's collapse. These relationships have evolved somewhat differently in Romania compared to Kazakhstan, despite both countries having semi-presidential systems. A comparative analysis helps us to better understand the role and place of the parliament in each of the respective countries. The authors identify similarities and differences of legislature-executive relations in post-communist Romania and post-Soviet Kazakhstan, while making some inference about the strength of legislatures. The article concludes with a summation that the frequent cases of no-confidence votes in Romania has resulted in an unstable government and, often, governmental crises, but at the same time, this indicates a relatively powerful parliament, whereas the non-existence of such practices in Kazakhstan has contributed to a strong, stable, and unanimous cabinet, but with a weak and subservient parliament.
\end{abstract}

UDC Classification: 328, DOI: http://dx.doi.org/10.12955/cbup.v3.655

Keywords: Parliament, post-socialist, president, Romania, Kazakhstan, parliamentary development, comparison

\section{Introduction}

A clear understanding of the interaction of parliaments with executive branches in post-socialist Romania and Kazakhstan, requires a thorough study of historical and institutional viewpoints of the parliamentary development in these respective countries. Since the parliamentary development in Romania and Kazakhstan has been studied previously in other projects, with results published elsewhere (Zhanarstanova \& Kanapyanov, 2011), we can directly compare the Parliament-PresidentGovernment relationship and infer the strength of the legislatures for both countries. Nevertheless, a brief institutional profile of the post-communist Romania and post-Soviet Kazakhstan follows.

The transition that was triggered by the collapse of communist rule in Romania and Kazakhstan is a part of the processes of what Huntington (1991) called the Third Wave of democratization, and these have involved states of East Central Europe and Central Asia in last few decades. Most researchers agree that "these states were faced with the enormous challenges of building democratic state institutions at the same time as building a nation; creating a national economy; and formulating their foreign policy orientation" (Whitmore, 2004, p. 1). Yet, the transition from communist rule to democratic order in the former communist countries evolved differently between countries. In other words, the post-communist history and the development of political institutions were varied substantially from country to country. Furthermore, "many state institutions were inherited from the Soviet period and were adapted to the new tasks of independent statehood, while Soviet-era officials continued to staff these institutions" (Whitmore, 2004, p. 1). Therefore, according to Whitmore (2004, p. 1) "these institutions where not designed for sovereign, rule-of-law states and were poorly equipped to manage the wider state transformations".

Despite sharing a communist past, Kazakhstan and Romania evolved quite differently in their postcommunist political order. Kazakhstan unwillingly accepted the break-up of the Soviet Union in 1991 and peacefully declared its independence, while the Romanian Revolution was the most bloody of all

\footnotetext{
${ }^{1}$ Timur Kanapyanov, Department of Political Science, L.N. Gumilyov Eurasian National University, kanapyanov@yahoo.com

${ }^{2}$ Naubat Kaliyev, Professor, Department of Political Science, L.N. Gumilyov Eurasian National University, naubat1045@mail.ru
} 
in East Central Europe. However, despite their geographical remoteness, and different cultural and historical backgrounds, ethnic and religious compositions and economic profiles, Romania and Kazakhstan share some common elements of communist legacy and byproducts during their postcommunist development of political institutions. Their respective experiences with communist rule and their transition to democracy were not necessarily similar. The legislature-executive relations within the two countries are contrasting, in terms of both stability and the level of institutionalization.

Nevertheless, weakly organized parliaments, with fragmented parties, have led to a presidential system of personal leadership in both countries: at least during the initial decade in Romania, and up to present day in Kazakhstan. Moreover, two decades of political development in both countries have resulted in semi-presidential systems with bicameral legislative bodies.

\section{Kazakhstan}

The Republic of Kazakhstan is one of the fifteen states that emerged after the dissolution of the Soviet Union. These states had a huge task of building democratic state institutions, which was no easy mission. While effective political institutions were necessary, the legislative institutions inherited from the Soviet Union were weak. Thus, according to Whitmore (2004, p. 1), post-Soviet parliaments were faced with the challenge of building capable, functioning institutions while operating as organized parliaments.

In this sense, the Republic of Kazakhstan was no exception. During the initial years of independence, the functions of legislature in Kazakhstan was performed by the unicameral symbolic Supreme Soviet, until the new Constitution of 1995 brought into political life the professional bicameral Parliament of Kazakhstan (Constitution of the Republic of Kazakhstan, 1995). Today, the Parliament of Kazakhstan has been institutionalized into a stable and efficient legislative body of the country, though it is highly controlled by the President. It has been transformed over time with Kazakhstan gaining independence in 1991. This kind of institutional change often invokes scientific interest and is worthy of analytical investigation.

\section{Romania}

After the collapse of communism and the revolution of 1989, Romania entered a new phase of political development. In the autumn of 1989, all communist countries in Central and Eastern Europe, one by one, witnessed the collapse of the old regime. The revolution and regimental change in Romania was abrupt and the most violent in the region (Gönenç, 2002, p. 146). Romania had been officially declared an independent country under communist regime, but this was under immense control of Moscow. Thus, for Romania, the regimental change of 1989 meant the regaining of its full independence with a more or less sudden break from a communist past. Although there was a communist elite continuity, the political institutions had to be recreated from 'scratch'.

Immediately following the revolution of December 1989, a provisional government formed in Romania, led by the National Salvation Front (FSN). This movement played a leading role during the events of December 1989 and as a result, was supported and accepted as a legitimate authority by most Romanians. According to Roper (2005, p. 65), the FSN established the parameters in which institutional decisions were made, and thus, was primarily responsible for the development of political institutions at the beginning of 1990s. This provisional revolutionary government created a twochamber parliamentary system and the Romanian Parliament has since evolved from the Constituent Assembly of 1990 to the professional and multi-party Parliament seen today. The legislature-executive relations in post-communist Romania was disproportionate and less stable in comparison to the established democracies of Western Europe, but even so, it was more stable and efficient than many post-Soviet countries. 
Hence, the comparative analysis of legislature-executive relations includes two post-socialist countries: Romania and Kazakhstan. In spite of the different geographical areas of these countries, in East Central Europe and Central Asia, there are important common denominators. For example, they share a communist past and each started the transition to democracy at approximately the same time, with similar political and economic problems in establishing their institutions.

\section{Parliament-Government interactions}

As previously mentioned, the relative strength of parliaments can be identified by comparing the parliament-president-government relationships of both countries. These relationships have evolved somewhat differently in Romania compared to Kazakhstan, despite both countries having semipresidential systems. A threefold relationship between the parliament-president-government has been predetermined by the emergence of more stable and consolidated party system in Romania, and the weak and fragmented parties 'coupled with the emergence of a presidential single dominant party' in Kazakhstan.

In both cases, the government formation depends on the consent of the Parliament, though this is more the case in Romania. In both countries, the President appoints the Prime Minister (PM) by a vote of confidence in the Parliament, but the authority for dismissing the PM differs considerably between these countries. In Romania, after the modification of Constitution in 2003, the President's constitutional powers were revised to disallow presidential dismissal of the PM from office. Unlike the Romanian counterpart, the President of Kazakhstan can dismiss the PM at his discretion. Nevertheless, in the post-communist history of Kazakhstan, obvious confrontations between the President and the PM have not taken place. Only minor tensions have occurred bilaterally between the President and the Parliament, and the Government and the Parliament. By contrast, in Romania, throughout the postcommunist period, uneasy relationships between the President and the Government and the Parliament have been ongoing.

In Romania, the parliamentary elections are a decisive step in the formation and survival of government. In all cases, the government has had parliamentary approval and the PM has been the leader of one of the coalition parliamentary parties. Besides, almost all cases involve the government forming from a multi-party coalition, except in the 1990 elections, when the FSN won a majority of seats. Moreover, Romania has experienced relatively few successful minority governments, including the Nicolae Văcăroiu government of 1992 and the Adrian Năstase cabinet of 2000. By contrast, the parliamentary elections of Kazakhstan have been somewhat irrelevant for forming and retaining government, due to the under-developed party system and a high degree of presidential power. In addition, in Kazakhstan, most parliamentary elections have been won by the presidential party NUR OTAN, which has held a majority of seats, and in elections of 2007 won all seats in the Majilis. As a result, Kazakhstan has had a one-presidential-party parliament, with very subservient Ministers of Parliament (MPs), who stand steadfast with the President. Under these circumstances, the formation of government is fully dependent on the discretion of the powerful president. On the other hand, in Romania, the government and parliament relationships have consistently been unstable and 'precarious', just like the president and government relationships. During the transition period in Romania, numerous no-confidence votes on the PM have been presented in Parliament, whereas in Kazakhstan only one such example exists. However, in both Kazakhstan and Romania, the Parliament only once successfully passed a motion of no confidence in the PM, and this was in 1994 and 2009, respectively.

In both countries, the Parliament has a primary authority in the law-making process. However, the strength of legislature in Romania and Kazakhstan has been somewhat weakened by the delegation of legislative initiative to other branches of power. For example, according to their constitutions, apart 
from that of the Parliament, in Romania, the Government has the right of a legislative initiative (Romania Const. art. 74, pt.1), while in Kazakhstan this right also pertains to the President (Kz Const. art. 61, pt. 1), if such a right was delegated by the Parliament. However, unlike Romania, Kazakhstan endows the President with "unfettered decree powers", resembling those of the Russian President (Norton \& Olson, 2007, p. 171). In both countries, the right of legislative delegation has been frequently abused, e.g. by the President of Kazakhstan and by the Government of Romania, and this has consequently led to "the only logical outcome being that the Parliament's role as the sole legislative body diminished" (Dimulescu, 2010, p. 117).

In both countries, the governments are accountable to the Parliament, although in Kazakhstan the government is primarily accountable to the President. In Romania, according to the Constitution, the government, and other bodies of public administration, are obliged to provide the parliament with any requested information or documents (Romania Const. art. 111, pt. 1), and the government is also bound to answer the question or interpellations raised by the deputies or senators (Romania Const. art. 112, pt. 1). The most important tool of the legislative control is the ability of the parliament to withdraw its vote of confidence in the government, by the motion of censure. The motion of censure may be initiated by at least a quarter of the total number of deputies and senators, and shall be notified in the government upon the date of its tabling (Romania Const. art. 113). In a similar vein, the Constitution of Kazakhstan provided the following: "The Majilis by a majority of votes from total number of deputies of the Majilis at the initiative of not less than one-five from total number of deputies of Majilis has the right to express a vote of no confidence in the Government" (Kz Const. art. $56)$.

In both countries, the parliaments have had considerable capacity to initiate a motion of censure in the government. This particular right of parliament has been apparent in both countries, though it has been used more often in Romania than in Kazakhstan. For instance, in Romania, between 1993 and 1994 there were three separate votes of no confidence in the Văcăroiu Government and in the beginning of 2011 five cases of censure motion in the Boc Government. These were successful. Such frequency of no-confidence motions in Romania results because of a multi-party coalition government with various parties in the parliament. By contrast, almost no such cases of censure motion have occurred in Kazakhstan due to the parliament being dominated by a presidential party highly controlled by the President, and the lack of strong and competitive parties both within and beyond the legislature. Nonetheless, as it has been discovered, in both countries, a successful vote of no confidence occurred only once, resulting in the resignation of Prime Minister Tereshchenko in 1994 in Kazakhstan and the resignation of Prime Minister Emil Boc in 2009 in Romania.

\section{Parliament-President interactions}

In Romania and Kazakhstan, the relationship between the President and parliament was somewhat stormy during the initial decade of transition. Both presidents, Iliescu and Nazarbayev, clearly stated their desires for a strong presidential system at the beginning of the transition. Of course, the parliament and parties were highly opposed to the strong presidency and strongly negotiated their positions concerning other power branches. The first two post-soviet parliaments in Kazakhstan, called the Supreme Soviet, were highly confrontational to the President and his government. This conflict resulted in the adoption of the first constitution of 1993, where the Supreme Soviet retained considerable powers. Most scholars agree that according to this constitution, Kazakhstan had a quasiparliamentary government with more powerful legislature than the President, and where the Supreme Soviet was still ineffective and weak. Because of the confrontation between the President and the Supreme Soviet, the first post-communist parliament was 'pushed' to self-dissolution in 1993. The second post-communist parliament, elected in 1994, was in no way less confrontational, as deemed by 
the President. It was very slow in law-making and in one year adopted only seven pieces of legislation, but in the same time span, managed to pass the only post-soviet history vote of no-confidence in the government. As a result, the Constitutional Court in 1995 dissolved the second post-communist parliament of Kazakhstan on the grounds of the unconstitutional elections of 1994. After the dissolution of this parliament, President Nazarbayev ruled the country by decree for about eight months during the parliamentary interim from March to December 1995, and during this time, he adopted a new constitution by referendum and enshrined a full-presidential system.

In Romania, at the beginning, President Iliescu also attempted to dominate the parliament and install a system of strong presidency. However, due to the existence of various oppositional, ethnic, and historical parties, Iliescu managed to secure a semi-presidential system (premier-presidential) only (Shugart \& Carey, 1992) with restrained presidential powers. Nevertheless, the President, through his party FSN/FDSN, which gained an absolute majority and a plurality of seats in 1990 and 1992, respectively, strongly controlled both the first and second post-communist parliaments of Romania. A division between the followers of Prime Minister Roman and that of President Iliescu distinguished the first post-communist parliament and thus the real confrontation was not between the executive and legislature, but rather between the President and the PM. However, Iliescu managed to secure his position during the second post-communist parliament and once more, subverted the parliamentary power. This parliament became more confrontational towards the President. The parliamentarians of the second parliament initiated the suspension of the President from office, although this was unsuccessful. Unlike Kazakhstan, the President of Romania had lost his positions in the 1996 presidential and parliamentary elections and the opposition, represented by the Romania Democratic Convention (CDR), came into power. During the presidency of President Constantinescu, between 1996 and 2000, the parliament became more active and independent. However, with the 2000 elections, the former communist party, represented by Iliescu and his party, the Social Democratic Party of Romania (PDSR), returned to power, although President Iliescu had less power in parliament than previously, due to the party system and the parliament becoming institutionalized and consolidated.

By contrast, President Nazarbayev retained his position and, over time, increasingly consolidated his powers. Today, despite having a semi-presidential system (president-parliamentary) (Shugart \& Carey, 1992), the absolute majority of the parliament consists of the NUR OTAN party and the President has much more power than the legislature. In both countries, during the initial decade, the presidents exerted considerably more power than did the parliament. In Romania, this occurred until 2004, when Iliescu and the former communist party were fully defeated (except 1996 and 2000), while in Kazakhstan, it remains the case today. Overall, the relationship between the president and the parliament in Romania and Kazakhstan was similar during the first decade, but in the second decade displayed sharp distinctions.

The sharp contrast between the parliaments of Romania and Kazakhstan partially relates to the different types of semi-presidentialism that are enshrined in the constitutions of these countries. According to Shugart and Carey's classification, Kazakhstan is a presidential-parliamentary type, while Romania is a premier-presidential kind. These two types differ largely in terms of the capacity of presidential power. A popular elected president, with mostly non-legislative constitutional powers and a cabinet dismissed exclusively by the legislature, distinguishes the premier-presidential from the presidential-parliamentary type, where the president has wide legislative functions and, with the parliament, can dismiss the government (Shugart \& Carey, 1992). Therefore, by the definition of its political systems, the President of Kazakhstan is much more powerful than his counterpart in Romania, and consequently, the legislature is less powerful in Kazakhstan than in Romania. For example, the President of Romania has no veto rights, whereas the President of Kazakhstan does. In 
addition, the President of Kazakhstan has the constitutional right to issue decrees that have the force of law, while in Romania such right of the President is limited. Again these 'unfettered decree powers' of the President of Kazakhstan contribute to a weak parliament.

In considering the presidential power to dissolve legislatures, under the Constitution of Romania, the Romanian President may dissolve parliament after consultation with the presidents of both parliamentary chambers and the leaders of parliamentary groups. This may occur in situations where the parliament has not been able to ratify a new government within the sixty-day period following the initial request, and only after rejection of at least two requests for investiture. Moreover, during the same year, the legislature can be dissolved only once (Romania Const. art. 89). According to Tănăsescu (2008, p. 84), these conditions are almost impossible to meet, therefore, this authority of President is purely nominal. By contrast, the Kazakhstan President can easily implement such procedures in his country. For instance, according to the Constitution of Kazakhstan, "The President of the Republic of Kazakhstan after consultations of the Chairpersons of the Chambers of the Parliament and the Prime Minister may dissolve the Parliament or the Majilis of the Parliament", although this also applies only once in a year (Kz Const. art. 63).

Clearly, regarding the authority of dissolution of parliament, the President of Kazakhstan has considerably more power than his Romanian counterpart. Hence, there has been a high number of prematurely dissolved parliaments in Kazakhstan compared to Romania, where the parliament has never been prematurely terminated in post-communist history. By the summer of 2011, Kazakhstan had six convocations of parliaments elected overall with half being prematurely dissolved whether by the President or by the 'own initiative' of parliamentarians, in 1993, 1995 and 2007. This supports the argument of having a weak and less institutionalized and less mature parliamentarism in Kazakhstan.

In terms of the 'checks and balances' in the political system, the parliaments of Romania and Kazakhstan have certain levers of presidential control. The main tool is the parliament's right of impeachment of the President. In both countries, the parliament has a right to discharge the president from office, but only in the case of high treason. In Romania, the constitutional text distinguishes between "suspension from office" and "impeachment", while in the Constitution of Kazakhstan no such distinctions exist. In the literature, the Romanian suspensions have generally related to presidential impeachment (Dimulescu, 2009). According to Article 95 of Romanian Constitution, the President may be suspended from office by a majority vote of deputies and senators and after consultation with the Constitutional Court when acts violating the Constitution have been committed. When suspension is successfully passed by the parliament, a referendum is to be held within 30 days in order to remove the President from office. The impeachment may take place, based on the votes of at least two thirds of the total deputies and senators and thus initiated simply by the majority of deputies and senators (Romania Const. art. 96).

In Kazakhstan, the parliamentary rights are almost identical to those of Romania in terms of the impeachment of the President. Namely, he "may be discharged from office only in the case of high treason" and "the decision to bring an accusation and conduct its investigation may be adopted by the majority of the deputies of the Majilis at the initiative of no less than one-third of the total number of its deputies" (Kz Const. art. 47).

Despite having almost the same rights of impeachment, the application of these procedures and the degree of using that power differ considerably between Romania and Kazakhstan. In the postcommunist legislative history of Romania, the Parliament used the power of suspension twice, namely, in 1994 against Ion Iliescu and then in 2007 against Traian Băsescu (Dimulescu, 2010), with both cases unsuccessful, while in post-Soviet Kazakhstan, the Parliament has never applied its impeachment power on the President. 


\section{Conclusion}

As described above, the relationship between the Parliament and the President during the second decade was stormy and unstable in Romania. While this was the case in Kazakhstan in the first decade, in the second decade these relations became most stable with the constant domination of the President. Several events confirm the confrontational stance between the Parliament and the President in Romania. These include the opposing stance of the Parliament towards Băsescu's proposal to substitute the bicameral parliament with an unicameral one in 2005 and the Parliament's impeachment of the President in 2007 and his successful suspension from office for 30 days, which subsequently failed in a referendum. These also involved the successful motion of no confidence of Prime Minister Emil Boc by the Parliament in 2009, and further rejection of a new PM proposed by the President. Additionally, there was the severe resistance of the Parliament to the referendum proposed by the President about changing two-chamber legislature and reducing the number of MPs to 300, which also failed because of resistance.

By contrast, the president-dominated nature of the Parliament of Kazakhstan and the smooth relations between the President and the Parliament is evident in recent events. These involve an almost unanimous adoption of the 2007 constitutional amendments by the Parliament. This introduced a notion of the 'first president' and conferred special rights on the first president by removing term limits and offering immunity from persecution; the unanimous adoption of the constitutional law in 2010 called 'A Leader of the Nation', by which the incumbent was granted greater privileges and protection. These also involved the Parliament's unanimous adoption of the constitutional law in 2011, according to which, the term of the 'first president' could be extended by the referendum for the indefinite time span, although the Constitutional Council held this law unconstitutional and subsequently abolished it.

Overall, the frequent cases of votes of no confidence in Romania have resulted in an unstable government and frequent governmental crises, but at the same time have indicated a relatively powerful parliament. Meanwhile, the non-existence of such practices in Kazakhstan has contributed to a strong, stable, and unanimous cabinet, but with a weak and subservient parliament.

\section{References}

Constitution of Romania (2003). Retrieved from http://www.cdep.ro/pls/dic/site.page?id=371

Constitution of the Republic of Kazakhstan (1995). Retrieved from http://www.akorda.kz/en/category/konstituciya

Dimulescu, V.A. (2009). The Institution of Presidential Impeachment in Semi-Presidential Systems: the Case Study of Romania (Unpublished master's thesis). Central European University, Budapest.

Dimulescu, V.A. (2010). The presidential impeachment in semi-presidential systems. case study: Romania 2007. EUROPOLIS Journal of Political Analysis and Theory, 4 (1), 101-132.

Gönenç, L. (2002). Prospects for Constitutionalism in Post-Communist Countries, Law in Eastern Europe, Vol. 50. Hague: Martinus Nijhoff Publishers.

Huntington, S.P. (1991). The Third Wave: Democratization in the Late Twentieth Century. Norman: University of Oklahoma Press.

Norton, P. \& Olson, D.M. (2007). Post-communist and post-soviet parliaments: divergent paths from transition. The Journal of Legislative Studies, 13 (1), 164-196.

Roper, S.D. (2005). Romania: The Unfinished Revolution. Taylor \& Francis e-Library.

Shugart, M.C. \& Carey, J.M. (1992). Presidents and Assemblies: Constitutional Design and Electoral Dynamics. Cambridge: Cambridge University Press.

Tănăsescu, E.S. (2008). Presidential elements in government. the President of Romania, or: The slippery slope of a political system. European Constitutional Law Review, 4, 64-97.

Whitmore, S. (2004). State-building in Ukraine. The Ukrainian parliament, 1990-2003. London and New York: RoutledgeCurzon.

Zhanarstanova, M. \& Kanapyanov, T. (2011). Development of Post-Communist Parliamentarism in Kazakhstan and Romania: a Comparative Analysis. Cinq Continents 1 (3), 198-217. 